\title{
PENERAPAN MODEL PEMBELAJARAN KOOPERATIF TPS UNTUK MENINGKATKAN HASIL BELAJAR SISWA PADA PELAJARAN IPS KELAS V SD
}

\author{
Auliau Rachman Zaman', Mas Subagio² \\ 1,2 PGSD FIP Universitas Negeri Surabaya \\ Auliau.rachmanpgsd@gmail.com
}

\section{INFO ARTIKEL}

\section{Riwayat Artikel:}

Diterima:22-Januari-2021

Disetujui:28-September-2021

\section{Kata Kunci:}

Kooperatif Tipe TPS, Hasil Belajar IPS

\section{ABSTRAK}

\begin{abstract}
Abstrak: Penelitian ini dilatar belakangi masih rendahnya hasil belajar siswa pada pelajaran IPS. Hal ini dikarenakan guru kurang kreatif dalam mengemas pembelajaran, sehingga siswa kurang memahami materi yang diajarkan. Solusinya dengan menerapkan model pembelajaran kooperatif tipe TPS. Tujuan penelitian ini adalah, mendeskripsikan aktivitas guru, siswa dan hasil belajar siswa dalam pembelajaran IPS dengan menerapkan model pembelajaran kooperatif tipe TPS. Penelitian ini merupakan Penelitian Tindakan Kelas. Teknik pengumpulan data yang digunakan adalah observasi, tes dan angket. Data dianalisis dan disajikan dalam bentuk deskriptif kuantitatif. Hasil penelitian menunjukkan bahwa hasil belajar siswa meningkat pada siklus I 64,71\% dan pada siklus II 94,18\%. Dapat disimpulkan bahwa penerapan model pembelajaran kooperatif tipe TPS dapat meningkatkan hasil belajar siswa di SDN Tawangsari III Sidoarjo.
\end{abstract}

\begin{abstract}
The background in this research study is still lower student learning result. Subject this because teachers are less creative in packaging of learning, so that students do not to understand the material being taught. The solution is to apply the model of cooperative learning use a type TPS. The purpose of this study is, to describe the activities of teachers, students and student learning result in learning by implementing cooperative learning model type TPS. This research use classroom action research as a method study. Data collection techniques used were observation, test and questionnaire. Data are analyzed and presented in the form of quantitative descriptive. The result showed that the learning outcomes of students increased $64.71 \%$ in the first cycle and the cycle II $94.18 \%$. It can be concluded that the implementation of cooperative learning model TPS can improve result of students in SDN Tawangsari III Sidoarjo.
\end{abstract}

\section{A. LATAR BELAKANG}

Di sekolah dasar terdapat berbagai mata pelajaran, salah satunya adalah mata pelajaran IPS. Dalam mata pelajaran IPS siswa harus memahami sepenuhnya dan mampu mengaplikasikannya dalam kehidupan sehari-hari. Pendidikan IPS sebagai bidang studi bukan hanya memberikan bekal pengetahuan saja tetapi juga memberikan bekal nilai dan sikap serta keterampilan dalam kehidupan peserta didik di masyarakat, bangsa, dan negara. Berkaitan dengan hal tersebut, pelaksanaan pembelajaran IPS di sekolah dasar harus dikelola dengan baik, dengan menggunakan model pembelajaran yang kreatif dan inovatif serta sesuai dengan tahap berfikir siswa sekolah dasar.

Berdasarkan hasil penelitian pada siswa kelas V SDN Tawangsari III Sidoarjo ditemukan berbagai kendala dalam pembelajaran IPS di SD yakni, : (1) siswa kurang dapat terlibat aktif dalam pembelajaran PKn karena siswa kurang minat dalam mata pelajaran IPS yang terdapat banyak hafalan dan proses pembelajaran IPS yang kurang menarik bagi siswa; (2) materi kurang dapat diterima dan dipahami siswa dengan baik karena kurangnya interaksi antar siswa dan antar guru dan siswa dalam proses pembelajaran, sehingga pembelajaran bersifat satu arah; (3) siswa kurang terdorong untuk berpikir kreatif dan kritis karena kondisi kelas yang kurang kondusif dan kurang menarik bagi siswa, kondisi lingkungan kelas masih tertata dengan meja dan bangku seperti pada umumnya yaitu menghadap kedepan papan tulis, hiasan ditembok juga masih minim; (4) tingkat pemahaman siswa terhadap informasi yang disampaikan masih kurang, siswa juga kurang bersemangat dalam pembelajaran, karena guru masih jarang menggunakan model pembelajaran inovatif. 
Menurut mereka penjelasan guru sulit dipahami, guru hanya mengandalkan bahasa verbal serta pembelajaran sering dianggap membosankan. Gaya bertutur dalam pembelajaran kurang menarik sehingga siswa hanya mendengarkan namun materi tidak dapat di terima dengan baik oleh siswa. Selain itu, siswa takut dan malu untuk bertanya jika ada hal yang tidak mereka pahami. Tidak ada interaksi siswa dalam bentuk kerjasama maupun diskusi. Siswa juga kurang berkesan dengan suasana kelas karena kondisi kelas yang kurang menarik dan kurang meriah.

Berbagai kendala dalam pembelajaran tersebut berdampak pada hasil belajar siswa rendah. Nilai siswa kelas V masih banyak yang berada di bawah nilai KKM (Kriteria Ketuntasan Minimal yang ditentukan oleh sekolah yaitu minimal 70). Oleh sebab itu, maka diadakanlah penelitian yang berjudul "Penerapan Model Pembelajaran Kooperatif Tipe TPS Untuk Meningkatkan Hasil Belajar Siswa Pada Mata Pelajaran IPS Kelas V SDN Tawangsari III Sidoarjo".

Berkaitan dengan permasalahan yang diidentifikasi dalam penelitian ini, proses pembelajaran yang inovatif dan kreatif mempunyai peran yang besar dalam keberhasilan pembelajaran. Menurut DePorter (2014:32) model pembelajaran kooperatif tipe TPS merupakan model pembelajaran yang berlangsung secara meriah dengan segala nuansanya. Pembelajaran ini berpusat pada siswa, dengan suasana kelas yang menyenangkan. Model pembelajaran kooperatif tipe TPS berfokus pada hubungan dinamis dalam lingkungan kelas, membentuk interaksi yang mendirikan landasan dan kerangka untuk belajar.

Untuk menciptakan suasana belajar yang menyenangkan dengan lingkungan yang mengasyikkan, aman dan nyaman, guru harus memperhatikan beberapa hal. Hal pertama adalah penataan lingkungan belajar yang dapat dilakukan di dalam ruang kelas maupun di luar kelas dan sekitarnya seperti, penataan bangku, hiasan dinding dengan gambar dan kata-kata yang mendorong inspirasi bagi siswa untuk belajar lebih cepat dan mengingat lebih banyak informasi. Kedua, guru dapat menciptakan susana belajar menyenangkan dengan musik atau media audio visual, sehingga menarik minat siswa untuk terus mengikuti pembelajaran dengan aktif.

Tujuan yang dicapai dalam penelitian ini adalah untuk, mendeskripsikan aktivitas guru dan siswa selama berlangsungnya pembelajaran IPS dengan menerapkan model pembelajaran kooperatif tipe TPS, mendeskripsikan hasil belajar siswa dalam pelajaran IPS dengan menerapkan model pembelajaran kooperatif tipe TPS.

\section{B. METODE PENELITIAN}

Berdasarkan tujuan penelitian yang berkaitan dengan pemecahan masalah dalam pembelajaran di kelas maka jenis penelitian yang digunakan dalam penelitian ini adalah Penelitian Tindakan Kelas (PTK). Hal ini sesuai dengan yang dipaparkan Suhardjono (2011). Penelitian Tindakan Kelas adalah penelitian tindakan yang dilakukan di kelas dengan tujuan untuk memperbaiki/meningkatkan mutu praktik pembelajaran. Penelitian ini akar permasalahannya muncul di kelas dan dirasakan langsung oleh guru. Guru juga dapat melakukan penelitian terhadap siswa dilihat dari aspek interaksinya dalam proses pembelajaran. Selain itu, guru juga dapat memperbaiki praktik pembelajaran yang dilakukan menjadi lebih berkualitas dan lebih efektif.

Penelitian yang sejalan disampaikan oleh Herawati Susila (2009), Penelitian Tindakan Kelas sebagai proses investigasi yang berdaur ulang dan bersifat reflektif dan mandiri yang dilakukan oleh guru/calon guru yang memiliki tujuan untuk melakukan perbaikan-perbaikan terhadap sistem, cara kerja, proses, isi, kompetensi, atau situasi pembelajaran.

Penelitian tindakan kelas ini menggunakan desain PTK model Kemmis \& Mc. Taggart melalui tiga siklus dengan empat komponen tahapan, yakni: (1) perencanaan, (2) pelaksanaan, (3) pengamatan, (4) refleksi. Peneliti melakukan persiapan sebelum melakukan penelitian untuk mempersiapkan segala sesuatu yang dibutuhkan dalam Penelitian Tindakan Kelas (PTK). Subjek penelitian ini dilaksanakan di kelas V SDN Tawangsari III Sidoarjo pada mata pelajaran IPS. Dalam penelitian ini yang menjadi subjek penelitian adalah siswa dan guru kelas V, dengan jumlah siswa sebanyak 17 siswa dengan rincian 7 siswa laki-laki dan 10 siswa perempuan.

Teknik pengumpulan data yang digunakan yaitu observasi, tes, dan angket. Data yang telah terkumpul dianalisis dan disajikan dengan menggunakan teknik analisis deskriptif kuantitatif. Analisis aktivitas guru dihitung dengan menggunakan rumus sebagai berikut.

$$
\mathrm{P}=\frac{\Sigma \mathrm{f}}{N} \times 100 \%
$$

Keterangan:

$\mathrm{P} \quad=$ Persentase aktivitas guru

$\sum \mathrm{f}=$ Banyaknya skor aktivitas guru yang diperoleh

$\mathrm{N}=$ Jumlah skor aktivitas keseluruhan 
Kriteria penilaian terhadap aktifitas guru sebagai berikut (Indarti, 2008)
$\geq 80 \%$
$60 \%-79 \%$
dinyatakan sangat baik
$40 \%-59 \%$
dinyatakan baik
$20 \%-39 \%$
dinyatakan cukup
$<20 \%$
dinyatakan kurang
dinyatakan sangat kurang

Analisis aktivitas siswa dihitung dengan menggunakan rumus sebagai berikut.

Keterangan :

$$
\mathrm{P}=\frac{\Sigma \mathrm{f}}{N} \times 100 \%
$$

$\mathrm{P}=$ Persentase aktivitas siswa

$\sum \mathrm{f}=$ Banyaknya skor aktivitas siswa yang diperoleh

$\mathrm{N}=$ Jumlah skor aktivitas keseluruhan

Kriteria penilaian terhadap aktifitas siswa sebagai berikut:
$\geq 80 \%$
$60 \%-79 \%$
dinyatakan sangat baik
$40 \%-59 \%$
dinyatakan baik
$20 \%-39 \%$
dinyatakan cukup
$<20 \%$
dinyatakan kurang
dinyatakan sangat kurang

Dari hasil nilai yang diperoleh siswa, selanjutnya dicari ketuntasan secara klasikal dengan rumus persentase sebagai berikut:

$$
\mathrm{P}=\frac{\mathrm{f}}{N} \times 100 \%
$$

Keterangan:

$\mathrm{P}=$ Pesentase ketuntasan klasikal

$\mathrm{f} \quad=$ Siswa yang tuntas belajar

$\mathrm{N}=$ Jumlah seluruh siswa dalam satu kelas

Dengan kriteria sebagai berikut:
$>80 \%$
dinyatakan sangat tinggi
$60 \%-79 \%$
dinyatakan tinggi
$40 \%-59 \%$
dinyatakan sedang
$20 \%-39 \%$
dinyatakan rendah
$<20 \%$
dinyatakan sangat rendah

(Aqib, 2009)

Berdasarkan rumusan masalah yang telah dirumuskan, maka indikator keberhasilan yang digunakan sebagai pengukur keberhasilan dalam penelitian ini adalah sebagai berikut : 1) Aktivitas guru dalam kegiatan pembelajaran dinyatakan berhasil jika aktivitas guru mendapatkan skor lebih dari atau sama dengan $80 \%$. 2) Aktivitas siswa dalam kegiatan pembelajaran dinyatakan berhasil jika aktivitas siswa mendapatkan skor lebih dari atau sama dengan 80\%. 3) Ketuntasan hasil belajar siswa secara klasikal dinyatakan berhasil jika mencapai lebih besar atau sama dengan $80 \%$, secara individu siswa dinyatakan berhasil apabila telah memenuhi KKM yakni lebih dari atau sama dengan 70 .

\section{HASIL DAN PEMBAHASAN}

HASIL PENELITIAN

Peneliti terlebih dahulu melakukan observasi awal untuk mengidentifikasi masalah yang terjadi dalam pembelajaran PKn kelas V SDN Tawangsari III Sidoarjo. Kemudian paparan hasil penelitian disajikan per siklus dengan tahapan mulai dari perencanaan, pelaksanaan, observasi dan refleksi. Adapun hasil penelitian dalam tiap siklusnya sebagai berikut. 


\section{Siklus I}

Tahap awal pada siklus I adalah peneliti melakukan perencanaan untuk melakukan proses pembelajaran yang meliputi: 1) Menelaah kurikulum. 2) Membuat perangkat pembelajaran, yang terdiri atas: a) menyusun silabus, b) menyususn RPP (Rencana Pelaksanaan Pembelajaran), c) menyususn LKS (Lembar Kerja Siswa) beserta kunci jawaban LKS, d) membuat media pembelajaran dan menentukan sumber ajar yang sesuai, e) membuat soal tes tulis sebagai alat evaluasi hasil belajar siswa, f) dan menyusun instrumen penelitian.

Tahap berikutnya adalah tahap pelaksanaan dan observasi. Pada tahapan ini, rencana pelaksanaan pembelajaran yang telah disusun sebelumnya diterapkan pada pelaksanaan pembelajaran di kelas. Pelaksanaan siklus sesuai dengan sintaks dalam model pembelajaran TPS. Penelitian pelaksanaan pembelajaran diamati oleh dua pengamat, yaitu guru kelas sebagai observer 1 dan teman sejawat peneliti sebagai observer 2 . Hasil analisis aktivitas guru pada siklus I dapat dilihat pada tabel berikut.

Tabel 1. Analisis Aktivitas Guru Siklus I

\begin{tabular}{|c|l|c|c|c|c|}
\hline No & \multicolumn{1}{|c|}{ Aspek yang Diamati } & Pengamat & P1 & P2 & Persentase \\
\hline 1. & Memberikan apersepsi/memotivasi siswa & 4 & 4 & 4 & $100 \%$ \\
\hline 2. & Menyampaikan tujuan pembelajaan & 3 & 3 & 3 & $75 \%$ \\
\hline 3. & Menginformasikan materi & 2 & 2 & 2 & $50 \%$ \\
\hline 4. & Membentuk kelompok belajar siswa & 3 & 3 & 3 & $75 \%$ \\
\hline 5. & Membagi teks konsep materi pelajaran & 2 & 2 & 2 & $50 \%$ \\
\hline 6. & Membentuk kelompok ahli & 3 & 3 & 3 & $75 \%$ \\
\hline 7. & Membimbing diskusi menyelesaikan LKS & 3 & 3 & 3 & $75 \%$ \\
\hline 8. & Menyimpulkan materi ajar yang telah diajarkan & 3 & 3 & 3 & $75 \%$ \\
\hline 9. & Memberi evaluasi & 4 & 4 & 4 & $100 \%$ \\
\hline Jumlah & $\mathbf{2 7}$ & $\mathbf{2 7}$ & $\mathbf{2 7}$ & $\mathbf{7 5 \%}$ \\
\hline
\end{tabular}

Setelah dilakukan rekapitulasi hasil observasi siklus I, selanjutnya perlu diketahui persentase keterlaksanaan aktivitas guru dalam kegiatan pembelajaran PKn dengan menerapkan model pembelajaran kooperatif tipe TPS. Secara klasikal persentase aktivitas guru dalam pembelajaran pada siklus I sebagai berikut:

Skor yang diperoleh $\quad=27$

Skor maksimal $\quad=36$

$$
\begin{gathered}
\text { Nilai }=\frac{\text { Skor yang diperoleh }}{\text { Skor maksimal }} \times 100 \\
: \text { Nilai }=\frac{27}{36} \times 100
\end{gathered}
$$

Keterangan:

$\mathrm{P}=$ Persentase keberhasilan

$\mathrm{f}=$ Jumlah skor aktivitas guru yang diperoleh

$\mathrm{N}=$ Jumlah skor maksimal

Hasil analisis aktivitas siswa pada siklus I dapat dilihat pada tabel berikut.

Tabel 2. Analisis Aktivitas Siswa Siklus I

\begin{tabular}{c|l|c|c|c|c}
\hline \multirow{2}{*}{ No } & \multicolumn{1}{|c|}{ Aspek yang Diamati } & \multicolumn{2}{c|}{ Pengamat } & \multirow{2}{*}{ RT } & $\begin{array}{c}\text { Persentase } \\
\%\end{array}$ \\
\cline { 3 - 4 } & & P1 & P2 & & 2 \\
\hline 1. & Memberi respon apersepsi & 2 & 3 & 2,5 & $62,5 \%$ \\
\hline 2. & Memperhatikan penjelasan guru & 3 & 3 & 3 & $75 \%$ \\
\hline 3. & Membaca teks materi bahan ajar & 3 & 3 & 3 & $75 \%$ \\
\hline 4. & Melakukan diskusi pada kelompok ahli & 2 & 2 & 2 & $50 \%$ \\
\hline 5. & Menjelaskan hasil diskusi pada pada kelompok asal & 3 & 3 & 3 & $75 \%$ \\
\hline 6. & $\begin{array}{l}\text { Kemampuan siswa bekerjasama dengan kelompok saat } \\
\text { diskusi }\end{array}$ & 2 & 3 & 2,5 & $62,5 \%$ \\
\hline
\end{tabular}




\begin{tabular}{c|l|c|c|c|c}
\hline 7. & Mempresentasikan hasil diskusi & 3 & 2 & 2,5 & $62,5 \%$ \\
\hline 8. & Keberanian mempresentasikan hasil kerja kelompok & 2 & 3 & 2,5 & $62,5 \%$ \\
\hline 9. & Menyimpulkan materi & 2 & 3 & 2,5 & $62,5 \%$ \\
\hline 10. & Mengerjakan soal evaluasi & 2 & 3 & 2,5 & $62,5 \%$ \\
\hline Jumlah & $\mathbf{2 4}$ & $\mathbf{2 8}$ & $\mathbf{2 6}$ & $\mathbf{6 5 \%}$ \\
\hline
\end{tabular}

Setelah dilakukan rekapitulasi hasil observasi siklus I, selanjutnya perlu diketahui persentase keterlaksanaan aktivitas siswa dalam kegiatan pembelajaran IPS dengan menerapkan model pembelajaran kooperatif tipe TPS. Secara klasikal persentase aktivitas siswa dalam pembelajaran pada siklus I sebagai berikut:

Skor yang diperoleh $=26$

Skor maksimal $=40$

$$
\text { Nilai }=\frac{\text { Skor yang diperoleh }}{\text { Skor maksimal }} \times 100
$$

$$
\text { Nilai }=\frac{26}{40} \times 100=65
$$

Keterangan:

$\mathrm{P}=$ Persentase keberhasilan

$\mathrm{f}=$ Jumlah skor aktivitas siswa yang diperoleh

$\mathrm{N}=$ Jumlah skor maksimal

Data hasil belajar siswa diperoleh dari tes yang diberikan kepada siswa untuk dikerjakan secara individu adalah sebagai berikut.

Tabel 3. Hasil Belajar Siswa Pada Siklus I

\begin{tabular}{l|l|c|c|c}
\hline \multirow{2}{*}{ No } & \multirow{2}{*}{ Nama Siswa } & \multirow{2}{*}{ Nilai } & \multicolumn{2}{c}{ Keterangan } \\
\cline { 4 - 5 } & & & Tuntas & $\begin{array}{c}\text { Tidak } \\
\text { Tuntas }\end{array}$ \\
\hline 1 & Snea & 64 & & $\sqrt{ }$ \\
\hline 2 & Ae & 80 & $\sqrt{ }$ & \\
\hline 3 & And & 70 & $\sqrt{ }$ & \\
\hline 4 & Ana & 70 & $\sqrt{ }$ & \\
\hline 5 & Aaf & 70 & $\sqrt{ }$ & \\
\hline 6 & Baw & 70 & $\sqrt{ }$ & \\
\hline 7 & Frs & 63 & & \\
\hline 8 & Hah & 60 & & $\sqrt{ }$ \\
\hline 9 & Mac & 62 & & $\sqrt{ }$ \\
\hline 10 & Mww & 70 & $\sqrt{ }$ & \\
\hline 11 & Mbas & 78 & $\sqrt{ }$ & \\
\hline 12 & Mnfa & 70 & $\sqrt{ }$ & \\
\hline 13 & Npy & 64 & & $\sqrt{ }$ \\
\hline 14 & Npgr & 75 & $\sqrt{ }$ & \\
\hline 15 & Nuk & 70 & $\sqrt{ }$ & \\
\hline 16 & Pfc & 80 & $\sqrt{ }$ & \\
\hline 17 & Rff & & $\mathbf{1 1}$ & $\mathbf{6}$ \\
\hline Jumlah & & $\mathbf{6 4 , 7 1 \%}$ & $\mathbf{3 5 , 2 9 \%}$ \\
\hline Persentase & & &
\end{tabular}

Secara klasikal persentase pada siklus I adalah sebagai berikut:

$$
\begin{aligned}
\mathrm{P} & =\frac{\sum \text { siswa yang tuntas belajar }}{\text { Banyak Siswa }} \times 100 \% \\
& =\underline{11} \times 100 \%=64,71 \%
\end{aligned}
$$

Sebaran nilai berdasarkan kriteria penilaian yang telah dikemukakan di atas adalah sebagai berikut. 
Tabel 4. Rentang Sebaran Nilai Hasil Belajar Siswa Siklus I

\begin{tabular}{|c|c|c|}
\hline Rentang Nilai & Jumlah Siswa & Persentase \\
\hline $80-100$ & 2 & $12 \%$ \\
\hline $66-79$ & 9 & $53 \%$ \\
\hline $56-65$ & 6 & $35 \%$ \\
\hline $40-55$ & 0 & 0 \\
\hline$\leq 40$ & 0 & 0 \\
\hline Jumlah & $\mathbf{1 7}$ & $\mathbf{1 0 0 \%}$ \\
\hline
\end{tabular}

Hasil penelitian yang telah diperoleh tersebut diklasifikasikan kedalam bentuk penskoran nilai siswa dengan menggunakan kriteria standart penilaian sebagai berikut.
$80-100$
$66-79$
dinyatakan baik sekali
$56-65$
dinyatakan baik
$40-55$
dinyatakan cukup
dinyatakan kurang

Setelah melakukan analisis data pada tahap sebelumnya, selanjutnya dilakukan tahapan refleksi Rencana Pelaksanaan Pembelajaran berupa strategi untuk implementasi pada siklus berikutnya melalui revisi dan perbaikan. Hasil pengamatan dan analisis data aktivitas guru, aktivitas siswa dan hasil belajar siswa pada siklus 1 menunjukkan bahwa penelitian belum mencapai indikator keberhasilan yang ditetapkan yaitu $80 \%$. Oleh karena itu, peneliti melakukan revisi terhadap rencana pelaksanaan pembelajaran yang telah disusun sebelumnya.

Berdasarkan hasil refleksi yang dilakukan guru (peneliti), guru kelas (observer 1) dan teman sejawat (observer 2). Pada siklus ini menunjukkan bahwa ada beberapa kendala yang dihadapi dalam pelaksanaan pembelajaran IPS dengan menggunakan model pembelajaran kooperatif tipe TPS. Adapun kendala tersebut adalah, (1) dalam menggunakan model pembelajaran kooperatif tipe TPS sudah sesuai sintaks, namun dalam pelaksanaanya kurang maksimal disetiap aspeknya. Hal ini dapat dilihat dari lembar observasi guru, ada beberapa tahapan yang mendapat skor 2 dengan kriteria cukup. (2) Guru kurang tegas memperhatikan siswa yang tidak aktif ataupun mengganggu pembelajaran. Hal ini dapat dilihat pada lembar observasi siswa, yang mana dalam hal memperhatikan penjelasan guru siswa hanya mendapat skor 2 dengan kategori cukup. Selain itu dalam mengerjakan Lembar Kegiatan Siswa (LKS) dan Lembar Penilaian (LP), siswa juga cenderung ramai sehingga suasana kelas kurang kondusif. (3) Guru kurang memberikan bimbingan pada saat diskusi. Sehingga dalam diskusi hanya sebagian siswa yang mendominasi, sedangkan siswa yang lain ramai dan mengganggu.

Kendala-kendala tersebut perlu adanya penanggulangan/memecahan. Adapaun solusinya adalah sebagai berikut, (1) Seharusnya dalam menggunakan model pembelajaran kooperatif tipe TPS, guru lebih memahami sintaks, sehingga dalam pelaksanaanya dapat berjalan baik sesuai dengan sintaks model pembelajaran TPS. (2) Guru hendaknya lebih tegas dan melakukan kontrak belajar dengan siswa, dimana dalam kontrak tersebut terdapat sanksi yang tegas bagi yang melanggarnya. Sehingga suasana kelas lebih terarah dan kondusif. (3) Guru hendaknya lebih intensif dalam memberikan bimbingan pada saat diskusi. Membimbing siswa yang mengalami kesulitan dalam melakukan diskusi kelompok sehingga tidak ada siswa yang lebih mendominasi.

Berdasarkan hasil refleksi yang telah dipaparkan, maka peneliti melakukan revisi rancangan pembelajaran yang akan dilaksanakan pada siklus II.

\section{Siklus II}

Selanjutnya, tahap awal pada siklus II adalah peneliti melakukan perencanaan untuk melakukan proses pembelajaran yang meliputi: 1) Menelaah kurikulum. 2) Membuat perangkat pembelajaran dengan model pembelajaran TPS, yang terdiri atas: a) menyusun silabus, b) menyusun RPP (Rencana Pelaksanaan Pembelajaran), c) menyusun revisi LKS (Lembar Kerja Siswa) beserta kunci jawaban LKS, d) membuat media pembelajaran dan menentukan sumber ajar yang sesuai, e) membuat soal tes tulis sebagai alat evaluasi hasil belajar siswa, f) dan menyusun instrumen penelitian.

Tahap berikutnya adalah tahap pelaksanaan dan observasi. Pada tahapan ini, Rencana Pelaksanaan Pembelajaran yang telah disusun sebelumnya diterapkan pada pelaksanaan pembelajaran di kelas. Pelaksanaan siklus sesuai dengan sintaks dalam model pembelajaran kooperatif tipe TPS. Penelitian pelaksanaan pembelajaran diamati oleh dua pengamat, yaitu guru kelas sebagai observer 1 dan teman sejawat peneliti sebagai observer 2 .

Hasil analisis aktivitas guru pada siklus II dapat dilihat pada tabel berikut. 
Tabel 9. Analisis Aktivitas Guru Siklus II

\begin{tabular}{|c|c|c|c|c|c|}
\hline \multirow{2}{*}{ No } & \multirow{2}{*}{ Aspek yang Diamati } & \multicolumn{2}{|c|}{ Pengamat } & \multirow{2}{*}{ RT } & \multirow{2}{*}{$\begin{array}{c}\text { Persentase } \\
(\%)\end{array}$} \\
\hline & & P1 & $\mathbf{P 2}$ & & \\
\hline 1. & Memberi apersepsi/memotivasi siswa & 3 & 4 & 3,5 & $87,5 \%$ \\
\hline 2. & Menyampaikan tujuan pembelajaran & 3 & 4 & 3,5 & $87,5 \%$ \\
\hline 3. & Menginformasikan materi & 3 & 4 & 3,5 & $87,5 \%$ \\
\hline 4. & Membentuk kelompok belajar siswa & 4 & 4 & 4 & $100 \%$ \\
\hline 5. & Membagi teks konsep materi pelajaran & 3 & 4 & 3,5 & $87,5 \%$ \\
\hline 6. & Membentuk kelompok ahli & 3 & 3 & 3 & $75 \%$ \\
\hline 7. & Membimbing diskusi menyelesaikan LKS & 4 & 4 & 4 & $100 \%$ \\
\hline 8. & Menyimpulkan materi ajar yang telah diajarkan & 3 & 3 & 3 & $75 \%$ \\
\hline 9. & Memberi evalusi & 4 & 4 & 4 & $100 \%$ \\
\hline & Jumlah & 30 & 34 & 32 & $\mathbf{8 8 , 8 9 \%}$ \\
\hline
\end{tabular}

Setelah dilakukan rekapitulasi hasil observasi siklus II, selanjutnya perlu diketahui persentase keterlaksanaan aktivitas guru dalam kegiatan pembelajaran IPS dengan menerapkan model pembelajara TPS. Secara klasikal persentase aktivitas guru dalam pembelajaran pada siklus II sebagai berikut:

Skor yang diperolah $=32$

Skor maksimal $=36$

$$
P=\frac{f}{N} \times 100
$$

$$
\begin{gathered}
\text { Nilai }=\frac{32}{36} \times 100 \\
\text { Nilai }=88,89
\end{gathered}
$$

Keterangan:

$\mathrm{P}=$ Persentase keberhasilan

$\mathrm{f}=$ Jumlah skor aktivitas guru yang diperoleh

$\mathrm{N}=$ Jumlah skor maksimal

\begin{tabular}{|c|c|c|c|c|c|}
\hline \multirow{2}{*}{ No } & \multirow{2}{*}{ Aspek yang Diamati } & \multicolumn{2}{|c|}{ Pengamat } & \multirow{2}{*}{ RT } & \multirow{2}{*}{$\begin{array}{c}\text { Persentase } \\
\%\end{array}$} \\
\hline & & P1 & $\mathbf{P 2}$ & & \\
\hline 1. & Memberi respon apersepsi & 4 & 4 & 4 & $100 \%$ \\
\hline 2. & Memperhatikan penjelasan guru & 4 & 4 & 4 & $100 \%$ \\
\hline 3. & Membaca teks materi bahan ajar & 3 & 4 & 3,5 & $87,5 \%$ \\
\hline 4. & Melakukan diskusi pada kelompok ahli & 3 & 3 & 3 & $75 \%$ \\
\hline 5. & Menjelaskan hasil diskusi pada kelompok asal & 3 & 3 & 3 & $75 \%$ \\
\hline 6. & $\begin{array}{l}\text { Kemampuan siswa bekerja sama dengan kelompok saat } \\
\text { diskusi }\end{array}$ & 4 & 4 & 4 & $100 \%$ \\
\hline 7. & Mempresentasikan hasil diskusi & 4 & 3 & 3,5 & $87,5 \%$ \\
\hline 8. & Keberanian mempresentasikan hasil kerja kelompok & 4 & 3 & 3,5 & $87,5 \%$ \\
\hline 9. & Menyimpulkan materi & 3 & 3 & 3 & $75 \%$ \\
\hline 10. & Mengerjakan soal evaluasi & 4 & 3 & 3,5 & $87,5 \%$ \\
\hline \multicolumn{2}{|c|}{ Jumlah } & 36 & 34 & 35 & $87,5 \%$ \\
\hline
\end{tabular}

Hasil analisis aktivitas guru pada siklus II dapat dilihat pada tabel berikut.

Tabel 10. Analisis Aktivitas Siswa Siklus II

Setelah dilakukan rekapitulasi hasil observasi siklus III, selanjutnya perlu diketahui persentase keterlaksanaan aktivitas siswa dalam kegiatan pembelajaran IPS dengan menerapkan model pembelajaran TPS. Secara klasikal persentase aktivitas siswa dalam pembelajaran pada siklus II sebagai berikut : 
Skor yang diperoleh $=35$

Skor maksimal $=40$

$$
\begin{aligned}
& P=\frac{f}{N} \times 100 \\
& \text { Nilai }=\frac{35}{40} \times 100 \\
& \text { Nilai }=87,5
\end{aligned}
$$

Keterangan:

$\mathrm{P}=$ Persentase keberhasilan

$\mathrm{f}=$ Jumlah skor aktivitas siswa yang diperoleh

$\mathrm{N}=$ Jumlah skor maksimal

Data hasil belajar siswa diperoleh dari tes yang diberikan kepada siswa untuk dikerjakan secara individu

\begin{tabular}{|c|c|c|c|c|}
\hline \multirow[b]{2}{*}{ No } & \multirow[b]{2}{*}{ Nama Siswa } & \multirow[b]{2}{*}{ Nilai } & \multicolumn{2}{|c|}{ Keterangan } \\
\hline & & & Tuntas & $\begin{array}{c}\text { Tidak } \\
\text { Tuntas }\end{array}$ \\
\hline 1 & Snea & 100 & $\sqrt{ }$ & \\
\hline 2 & $\mathrm{Ae}$ & 85 & $\sqrt{ }$ & \\
\hline 3 & And & 85 & $\sqrt{ }$ & \\
\hline 4 & Ana & 92 & $\sqrt{ }$ & \\
\hline 5 & Aaf & 85 & $\sqrt{ }$ & \\
\hline 6 & Baw & 83 & $\sqrt{ }$ & \\
\hline 7 & Frs & 100 & $\sqrt{ }$ & \\
\hline 8 & Hah & 87 & $\sqrt{ }$ & \\
\hline 9 & Mac & 63 & & $\sqrt{ }$ \\
\hline 10 & Mww & 100 & $\sqrt{ }$ & \\
\hline 11 & Mbas & 90 & $\sqrt{ }$ & \\
\hline 12 & Mnfa & 70 & $\sqrt{ }$ & \\
\hline 13 & Npy & 80 & $\sqrt{ }$ & \\
\hline 14 & Npgr & 86 & $\sqrt{ }$ & \\
\hline 15 & Nuk & 95 & $\sqrt{ }$ & \\
\hline 16 & $\mathrm{Pfc}$ & 79 & $\sqrt{ }$ & \\
\hline 17 & Rff & 75 & $\sqrt{ }$ & \\
\hline \multicolumn{3}{|c|}{ Jumlah } & 16 & 1 \\
\hline \multicolumn{3}{|c|}{ Persentase } & $94,18 \%$ & $\mathbf{5 , 8 8 \%}$ \\
\hline
\end{tabular}
adalah sebagai berikut.

Tabel 11. Hasil Belajar Siswa Pada Siklus II

Secara klasikal persentase pada siklus II adalah sebagai berikut:

$$
\begin{aligned}
\mathrm{P} & =\frac{\sum \text { siswa yang tuntas belajar }}{\text { Banyak Siswa }} \times 100 \% \\
=\underline{16} & \times 100 \%=94,18 \%
\end{aligned}
$$

Sebaran nilai berdasarkan kriteria penilaian yang telah dikemukakan di atas adalah sebagai berikut.

Tabel 12. Rentang Sebaran Nilai Hasil Belajar Siswa Siklus II

\begin{tabular}{|c|c|c|}
\hline Rentang Nilai & Jumlah Siswa & Persentase \\
\hline $80-100$ & 12 & $71 \%$ \\
\hline $70-79$ & 4 & $24 \%$ \\
\hline $60-69$ & 1 & $6 \%$ \\
\hline $50-59$ & 0 & 0 \\
\hline$\leq 50$ & 0 & 0 \\
\hline Jumlah & $\mathbf{1 7}$ & $\mathbf{1 0 0 \%}$ \\
\hline
\end{tabular}


Hasil penelitian yang telah diperoleh tersebut diklasifikasikan kedalam bentuk penskoran nilai siswa dengan menggunakan kriteria standart penilaian sebagai berikut.

$\begin{array}{ll}80-100 & \text { dinyatakan baik sekali } \\ 66-79 & \text { dinyatakan baik } \\ 56-65 & \text { dinyatakan cukup } \\ 40-55 & \text { dinyatakan kurang }\end{array}$

Berdasarkan hasil refleksi yang dilakukan guru (peneliti), guru kelas (observer 1) dan teman sejawat (observer 2). Pada siklus ini menunjukkan bahwa pelaksanaan pembelajaran sudah berjalan dengan sangat baik. Semua aktivitas guru maupun aktivitas siswa telah mencapai indikator yang telah ditetapkan, yaitu aktivitas guru $88,89 \%$ dan aktivitas siswa 87,5\%. Hasil belajar siswa pada siklus II mengalami peningkatan dibandingkan dengan hasil belajar siswa pada siklus I dari 64,71\% (pada siklus I) menjadi 94,18\% (pada siklus II). Hal ini menunjukkan bahwa hasil belajar siswa sudah melampaui kriteria yang ditetapkan yaitu $80 \%$. Kendala-kendala yang muncul pada siklus I dan siklus II pembelajaran berhasil diatasi dan berjalan sesuai dengan solusi perbaikan yang diharapkan.

\section{PEMBAHASAN}

Pada bab ini akan dipaparakan pembahasan data yang diperoleh dari Siklus I dan Siklus II pada penelitian penerapan model pembelajaran kooperatif tipe TPS untuk meningkatkan hasil belajar siswa pada pelajaran IPS kelas V SDN Tawangsari III Sidoarjo. Paparan pembahasan disajikan berdasarkan rumusan masalah yang telah ditetapkan. Adapun pembahasannya sebagai berikut.

Berdasarkan hasil analisis data aktivitas guru pada Siklus I dan Siklus II persentase tingkat keberhasilan masing-masing Siklus dapat dilihat pada tabel berikut.

\begin{tabular}{c|l|c|c}
\hline \multirow{2}{*}{ No } & \multicolumn{2}{|}{ Aspek Yang Diamati } & \multicolumn{2}{c}{ Skor } \\
\cline { 3 - 4 } & & Siklus I & Siklus II \\
\hline 1 & Memberi apersepsi/memotivasi siswa & 4 & 3,5 \\
\hline 2 & Menyampaikan tujuan pembelajaran & 3 & 3,5 \\
\hline 3 & Menginformasikan materi & 2 & 3,5 \\
\hline 4 & Membentuk kelompok belajar siswa & 3 & 4 \\
\hline 5 & Membagi teks konsep materi pelajaran & 2 & 3,5 \\
\hline 6 & Membentuk kelompok ahli & 3 & 3 \\
\hline 7 & Membimbing diskusi menyelesaikan LKS & 3 & 4 \\
\hline 8 & Menyimpulkan materi ajar yang telah diajarkan & 3 & 3 \\
\hline 9 & Memberi evaluasi & 4 & 4 \\
\hline Jumlah & $\mathbf{2 7}$ & $\mathbf{3 2}$ \\
\hline Rata-rata & $\mathbf{3}$ & $\mathbf{3 , 5 6}$ \\
\hline Persentase (\%) & $\mathbf{7 5}$ & $\mathbf{8 8 , 8 9}$ \\
\hline
\end{tabular}

Dari tabel 13 dapat diketahui bahwa aktivitas guru selama siklus I sudah baik meskipun belum mencapai ketuntasan yang telah ditetapkan. Selama pembelajaran pada siklus I terdapat aspek yang terlaksana dengan baik dan yang kurang baik. adanya aktivitas guru yang masih memperoleh skor rata-ratadengan kategori "Cukup" yaitu: (1) melakukan apersepsi belum sesuai dengan materi yang akan diajarkan, (2) menyampaikan tujuan kurang jelas, (3) membagi siswa dalam kelompok yang heterogen namun kurang bisa membimbing proses berjalannya diskusi, (4) melaksanakan evaluasi dengan soal-soal pada Lembar Penilaian (LP)namun kurang dapat mengkondisikan saat siswa mengerjakan LP, (5) melakukan refleksi dan memberikan tugas tindak lanjut berupa PR atau tugas lainnya, dalam pelaksanaan refleksi guru kurang aktif dan kurang jelas.

Aktivitas guru yang mendapat skor rata-rata dengan kategori "Baik" yaitu: (1) membuka pembelajaran dengan mempersiapkan siswa, mengajak do'a dan presensi, (2) memberikan motivasi dan nasehat serta mengajak siswa untuk ice breaking, motivasi dan ice breaking yang diberikan sudah sesuai dengan materi yang akan disampaikan, (3) menggunakan model pembelajaranJigsaw sesuai sintaks.Aspek-aspek tersebut nantinya akan dijadikan motivasi dalam melaksanakan perbaikan pada siklus berikutnya. 
Dengan demikian aktivitas guru dari siklus I-II mengalami peningkatan. Hal ini dikarenakan pelaksanaan pembelajaran sudah sesuai dengan sintaks dan sesuai dengan teori pembelajaran model TPS, yakni denganmenciptakan lingkungan belajar secara efektif, dengan cara menggunakan unsur yang ada pada siswadan lingkungan belajarnya melalui interaksi yang terjadi di dalam kelas.Hasil yang diperoleh menunjukkan bahwa aktivitas guru dalam model pembelajaran TPSpada pelajaran IPSkelas V SD sudah mengalami peningkatan yang lebih baik dan hasilnya sudah mencapai kriteria ketuntasan minimal. Dari tabel diatas bisa kita lihat bahwa persentase aktivitas guru secara klasikal meningkat dengan sangat signifikan, dari siklus I sebesar 75\% menjadi $89 \%$ pada siklus II.

Diketahui bahwa aktivitas siswa selama siklus I sudah baik meskipun belum mencapai ketuntasan yang telah ditetapkan. Selama pembelajaran pada siklus I terdapat aspek yang terlaksana dengan baik dan yang kurang baik. Hal itu terjadi karena adanya aktivitas siswa yang masih memperoleh skor rata-ratadengan kategori "Cukup" yaitu : (1) dalam memperhatikan penjelasan guru, hanya sebagian siswa yang terlibat aktif dan sebagian lainnya kurang aktif, (2) dalam mengerjakan LKS, hanya sebagian siswa yang ikut serta dalam diskusi dan sebagian lainnya bermain atau berbicara sendiri, (3) dalam merespon pertanyaan umpan balik juga hanya sebagian siswa yang ikut terlibat aktif, (4) kemudian siswa yang ikut serta dalam menyimpulkan materi pembelajaran yang telah dilakukan hanya beberapa siswa. Aktivitas siswa yang mendapatkan skor dengan kategori “'Baik" yaitu: (1) siswa aktif dalam mendengarkan motivasi dari guru dan aktif mengikuti kegiatan ice breaking, (2) dalam proses pembelajaran yang dilakukan sudah sesuai dengan sintaks meskipun kurang beberapa aspek tidak terlaksana. Aktivitas siswa dalam merespon apersepsi sangat baik sekali siswa sangat aktif dalam kegiatan ini. Aspek-aspek tersebut nantinya akan dijadikan motivasi dalam melaksanakan perbaikan pada siklus berikutnya.

Setelah diadakan perbaikan pada siklus II diperoleh hasil yang sangat baik.Hal ini dapat dilihat dalam memberi respon persepsi, memperhatikan motivasi dan mengikuti ice breakingsiswa sangat aktifdan semangat sehingga mencapai kategori sangat baik. Selanjutnya dalam memperhatikan penjelasan guru (tujuan dan materi pembelajaran) siswa sangat aktif dalam tanya jawab dan mencatat materi yang disampaikan. Penerapan model pembelajaran TPS sudah sistematis dan terlaksana dengan baik, dalam mengerjakan LKS, dalam respon pertanyaan umpan balik pada saat mengerjakan soal evaluasi dan dalam merespon kegiatan penutup siswa aktif sehingga kondisi kelas sangat hidup dengan diskusi dan tanya jawab yang dilakukan siswa dengan guru maupun siswa dengan siswa, dalam aspek ini terlaksana dengan sangat baik.

Dengan demikian aktivitas siswa dari siklus I-II mengalami peningkatan. Peningkatan aktivitas siswa disetiap siklusnya sesuai dengan tujuan pembelajaran model TPS menurut Rusman (2012) yaitu: (1) meningkatkan partisipasi siswa, (2) meningkatkan daya ingat, (3) meningkatkan rasa kebersamaan, (4) meningkatkan daya dengar, (5) meningkatkan keharusan perilaku, dan mengubah nuansa pembelajaran antara guru dan murid, yang sebelumnya satu arah menjadi dua arah. Hasil ini menunjukkan bahwa aktivitas siswa dalam model pembelajaran TPS pada pelajaran IPS kelas V SD sudah mengalami peningkatan yang lebih baik dan hasilnya sudah mencapai kriteria ketuntasan sesuai indikator yang ditetapkan.

Temuan awal menunjukkan kategori sangat kurang hal ini menunjukkan bahwa 7 siswa memperoleh ketuntasan belajar yang ditetapkan sekolah dan 10 siswa belum mencapai kriteria ketuntasan belajar yang ditetapkan. Maka dari itu dilakukan perbaikan pembelajaran PKn melalui penelitian tindakan kelas.

Hasil belajar pada siklus I menunjukkan bahwa siswa setelah mengikuti pembelajaran dengan menggunakan model pembelajaran kooperatif tipe TPS memperoleh ketuntasan belajar dengan kategori cukup. Meskipun hasil belajar siswa pada siklus I meningkat dari hasil belajar siswa pada temuan awal dengan kategori cukup. Namun, hal ini masih kurang dari indikator keberhasilan yang ditetapkan. Secara keseluruhan siswa yang mengikuti tes sebanyak 17 siswa. Ini berarti ada 11 siswa yang memperoleh nilai diatas KKM dan 6 siswa yang mendapat nilai kurang dari KKM.

Hasil belajar pada siklus II menunjukkan bahwa siswa setelah mengikuti pembelajaran dengan menggunakan model pembelajaran kooperatif tipe TPS memperoleh ketuntasan belajar mencapai kategori baik sekali atau 16 siswa mendapat nilai lebih dari 70. Secara keseluruhan siswa yang mengikuti tes pada siklus II ini sebanyak 17 siswa. Hal ini menandakan bahwa hasil belajar siswa pada siklus II sudah mencapai indikator ketuntasan yang ditetapkan. Dengan meningkatnya hasil belajar siswa pada siklus I - II di atas, maka pemahaman siswa juga meningkat. Hal ini dikarenakan siswa sudah mulai mengenal dan terbiasa dengan model pembelajaran yang digunakan oleh guru dalam menyampaikan materi pelajaran. Siswa akan lebih bisa memahami materi yang disampaikan oleh guru.

\section{SIMPULAN DAN SARAN}

Berdasarkan hasil penelitian yang telah dilakukan, berkaitan dengan rumusan masalah dan tujuan penelitian maka dapat disimpulkan sebagai berikut: 1) Aktivitas guru selama penerapan model pembelajaran kooperatif tipe TPS dalam pembelajaran materi pengaruh globalisasi pada lingkungan di kelas V mengalami peningkatan. Hal ini 
ditunjukkan dengan adanya peningkatan hasil persentase aktivitas guru selama pembelajaran berlangsung pada setiap siklusnya. 2) Aktivitas siswa selama penerapan model pembelajaran kooperatif tipe TPS dalam pembelajaran materi pengaruh globalisasi pada lingkungan di kelas $\mathrm{V}$ mengalami peningkatan. Hal ini ditunjukkan dengan adanya peningkatan hasil persentase aktivitas siswa selama pembelajaran pada setiap siklusnya. 3) Hasil belajar siswa kelas V pada materi pengaruh globalisasi pada lingkungan di kelas V mengalami peningkatan setelah penerapan model pembelajaran kooperatif tipe TPS. Penilaian tes hasil belajar siswa meningkat pada setiap siklusnya.

Hasil penelitian menunjukkan bahwa penerapan model pembelajaran kooperatif tipe TPS dapat meningkatkan aktivitas guru dan siswa serta meningkatkan hasil belajar siswa pada materi pengaruh globalisasi pada lingkungan, maka peneliti menyampaikan saran sebagai berikut : 1) Kepada guru kelas untuk lebih inovatif dan kreatif dalam menciptakan dan memilih model yang sesuai dengan materi pembelajaran, agar materi dapat diterima siswa secara maksimal. Salah satunya dengan menerapkan model pembelajaran kooperatif tipe TPS. 2) Untuk melaksanakan pembelajaran yang menyenangkan, guru hendaknya lebih kreatif dalam merancang Rencana Pelaksanaan Pembelajaran dengan maksud supaya siswa lebih tertarik dan bersemangat belajar. Hal tersebut dapat dilakukan oleh guru dengan cara mengganti metode atau model pembelajaran secara rutin dalam pembelajaran. 3) Dalam pembelajaran guru disarankan untuk lebih detail dalam memilih model dan media pembelajaran. Dengan model dan media yang sesuai dapat mendukung kegiatan pembelajaran. Memilih model dan media pembelajaran yang sesuai dapat dilakukan dengan cara mengumpulkan referensi online maupun buku tentang model pembelajaran beserta media yang cocok digunakan untuk meningkatkan hasil belajar siswa.

\section{DAFTAR RUJUKAN}

[1] Aqib, Zainal. 2010. Profesionalisme Guru dalam Pembelajaran Surabaya: Insan Cendekia.

[2] Arikunto Suharsimi. 2010. Prosedur Penelitian. Jakarta: Rineka Cipta.

[3] Arikunto, Suharsimi dan Suhardjono. 2011. Penelitian Tindakan Kelas. Jakarta: PT Bumi Aksara.

[4] Asrori, Mohammad. 2007. Penelitian Tindakan Kelas. Bandung: CV Wacana Prima.

[5] DePorter, Bobbi \& dkk. 2014. TPS. Bandung: Kaifa.

[6] Gunawan, Rudy. 2011. Pendidikan PKn Filosofi, Konsep dan Aplikasi. Bandung: Alfabeta

[7] Indarti, Titik. 2008. Penelitian Tindakan Kelas (PTK) dan Penulisan Ilmiah. Surabaya: FBS Unesa.

[8] Purwanto. 2014. Evaluasi Hasil Belajar. Yogyakarta: Pustaka Belajar.

[9] Rusman. 2012. Model-Model Pembelajaran Mengembangkan Profesionalisme Guru. Jakarta: PT Rajagrafindo Persada. 